IZA DP No. 10207

Job Design and Skill Developments in the Workplace

Giovanni Russo

September 2016 


\title{
Job Design and Skill Developments in the Workplace
}

\author{
Giovanni Russo
}

Cedefop and IZA

\section{Discussion Paper No. 10207 \\ September 2016}

\author{
IZA \\ P.O. Box 7240 \\ 53072 Bonn \\ Germany \\ Phone: +49-228-3894-0 \\ Fax: +49-228-3894-180 \\ E-mail: iza@iza.org
}

\begin{abstract}
Any opinions expressed here are those of the author(s) and not those of IZA. Research published in this series may include views on policy, but the institute itself takes no institutional policy positions. The IZA research network is committed to the IZA Guiding Principles of Research Integrity.

The Institute for the Study of Labor (IZA) in Bonn is a local and virtual international research center and a place of communication between science, politics and business. IZA is an independent nonprofit organization supported by Deutsche Post Foundation. The center is associated with the University of Bonn and offers a stimulating research environment through its international network, workshops and conferences, data service, project support, research visits and doctoral program. IZA engages in (i) original and internationally competitive research in all fields of labor economics, (ii) development of policy concepts, and (iii) dissemination of research results and concepts to the interested public.
\end{abstract}

IZA Discussion Papers often represent preliminary work and are circulated to encourage discussion. Citation of such a paper should account for its provisional character. A revised version may be available directly from the author. 
IZA Discussion Paper No. 10207

September 2016

\section{ABSTRACT}

\section{Job Design and Skill Developments in the Workplace ${ }^{1}$}

We investigate the relationship between job complexity and the skills development of adult workers in Europe using the Cedefop European Skills and Jobs Survey (ESJS). The results suggest that challenging workplaces, workplaces in which jobs are designed to include complex tasks, and which place high demands on workers' skills, also stimulate workers' skills development. Increasing the degree of job complexity has positive and robust effects on the degree of skill development, and so does an increase in work experience (tenure). The analysis stresses the importance of on-the-job learning and contextual workplace characteristics for adult workers' skills development.

JEL Classification: J24

Keywords: job characteristics, job complexity, skills, skills development, learning

Corresponding author:

Giovanni Russo

European Centre for the Development of Vocational Training (Cedefop)

PoBox 22427

55102 Finikas, Thessaloniki

Greece

E-mail: giovanni.russo@cedefop.europa.eu

\footnotetext{
${ }^{1}$ The views expressed in the paper are solely the authors' and do not necessarily represent those of the European Centre for the Development of Vocational Education and Training (Cedefop). Two anonymous referees and Daniel Scheuregger provided useful comments that improved the quality of the paper. The usual disclaimer applies.
} 


\section{Introduction}

The workplace is not only a place where skills are demanded; it is also a place in which skills formation takes place (Heckman 2000). The learning curve (or experience curve) acknowledges the positive (albeit non-linear) relationship between performance (productivity) and work experience (i.e. job tenure) arising from learning-by-doing (Arrow 1962; Anzai and Simon 1979; Klenow 1998; Levitt, List et al. 2013; Besanko, Doraszelski et al. 2014).

In fact, workplaces that place high demands on workers' skills may also be workplaces that support skills development. Complex job designs and jobs designed to motivate workers while placing high demand on workers' skills (Pouliakas and Russo 2015) can have positive consequences for workers and organizational learning (Gibbs, Levenson et al. 2010; Osterman and Shulman 2011; Parker 2014).

Job complexity favours learning because complex job tasks require and stimulate intellectual and cognitive activity (Kahneman 2011). On-the-job learning may result from self-reflection on mistakes (Luthans, Youssef et al. 2006). Job control - autonomy to decide on how to perform job tasks - is an important job characteristic when it comes to learning because workers with autonomy can search for strategies to deal with non-routine work situations and can use their knowledge to choose the most promising among the strategies identified. This search and selection process fosters learning (Parker 2014).

Organizations may influence the amount of learning that takes place; if mistakes made in less complex jobs are, on average, less costly to the firm than mistakes made in more complex jobs, organizations may support workers' learning by providing career paths whereby individuals will first master less complex jobs and then be promoted to more complex ones (Jovanovic and Nyarko 1995). Training provision is another typical example of how firms can support the learning opportunities afforded by complex job design.

Gaining better understanding of the relationship between skills utilization and skills development is important because skills development in the workplace is a worldwide phenomenon with a real impact on productivity.

If jobs put strain on workers' skills and afford broad learning opportunities, organizations may become learning environments in which human capital can grant sustainable product market advantage (Boxall and Purcell 2011; Ployhart and Moliterno 2011; Beaudry, Green et 
al. 2013; Sterling and Boxall 2013; Sung and Ashton 2015). For example, human capital can sustain quality improvements and product and process innovation (Ichniowski, Levine et al. 2000). It can also sustain organizations' ability to innovate and adopt new technologies (Argote and Miron-Spektor 2011; Argote 2013), making organizations resilient to market fluctuations (Pal, Torstensson et al. 2014). The Resource Based View (RBV) posits that the knowledge and the skills accumulated within organisations are rare (specific), valuable, and hard to imitate (Barney 2001; Hult, Ketchen et al. 2005; Ketchen, Hult et al. 2007). ${ }^{2}$ They are an intangible asset for the organization (Beaudry, Green et al. 2013), ${ }^{3}$ one that contributes to organisational success (Molloy, Chadwick et al. 2011; Smithey Fulmer and Ployhart 2014). The link between human capital and business success is known to managers; they rank knowhow and knowledge as the second most important intangible assets after the reputation of the organisation or of the product (brand asset). Managers are also keenly aware of the time needed to build human capital, and that such capital is subject to depreciation: managers estimate that it takes about five years to build a satisfactory knowledge base (Hall 1992), and they consider training (investment in human capital) to remain valid for about three years (Awano, Franklin et al. 2010).

This paper focuses on the degree of skills development experienced by workers in the workplace, setting it in relation to changes in the perceived complexity of their jobs while controlling for workers' characteristics and organizational features. To our knowledge, this is the first time that this has been done.

The analysis is based on a data set that is cross-sectional in nature; as such a causal relationship can be derived only from supporting theoretical arguments. Yet the analysis may deliver valuable results because of the rich set of variables influencing skill formation contained in the data set. The study has the following defining characteristics. First, it can rely on a measure of skills development. Since skills are notoriously hard to observe and to measure (Green 2013) the study relies on a subjective measure of perceived overall skills development (knowledge, skills and ability) which encompasses skills formation through all

\footnotetext{
${ }^{2}$ Moreover, to provide competitive advantage, human capital should be unique and costly to imitate; but these features will lead to hold-up problems and to tensions between ownership and labour on the division of the economic rent generated by the competitive advantage (Blair 2011). Consequently, human resource practices supporting workers' motivation and willingness to apply their skills need to be put in place (Kaufman 2010; Kaufman 2010; Coff and Kryscynski 2011; Kaufman and Miller 2011).

${ }^{3}$ Other intangible assets are, for example, organisation and product reputation, patents, design solutions, software and data bases. The management of the supply chain, which is a vital source of competitiveness for lean organisations and modern manufacturing, can also be considered an intangible asset (Wowak, Craighead et al. 2013).
} 
modes of delivery (formal, informal, non-formal, training and on-the-job). The availability of a skill development measure is a rare feature. In general, human capital development has been measured by proxy, taking participation in various learning activities through which skills can be learnt (on-the-job training, interaction with colleagues, formal education, learning on the job etc. ) as the measure of the human capital formation (Marsick and Watkins 2003; Watkins and Marsick 2003; Yang, Watkins et al. 2004; Marsick 2013). Similarly, a Korean study used the self-reported importance of executing own tasks or peer exchange for skill development found in the Korean company survey (Jeon and Kim 2012). Finally, human capital accumulation has been indirectly measured by wage increases (after training) in a UK study based on the UK skill survey, which also considered an item tapping whether the job required the job holder to learn new things (Felstead, Gallie et al. 2010).

Second, empirical analyses of workplace learning have focused on change in performance on a given task or on a narrow set of skills developed through training. ${ }^{4}$ For example, a large number of US studies summarized through meta-analysis returned a positive impact of training on knowledge (declarative knowledge) and on the acquisition of specific skills (Colquitt, LePine et al. 2000). Another meta-analytical study (based on about 60 studies) found that job design had a positive relationship with specific measures of performance in specific tasks (Wielenga-Meijer, Taris et al. 2010). On the contrary, the measure of skills development used in the present study provides a comprehensive assessment of how workers' skills have changed (in the current employment spell). ${ }^{5}$

Third, the analysis benefits from an unusually rich set of control variables. It contains an expanded list of personal characteristics - including a measure of the attitude toward learning, and the importance of various aspects (among them the opportunity to use skills) for accepting the current job - influencing skill formation. The data set also contains retrospective information on workers' careers - promotions, changes in tasks, and horizontal mobility. Finally, while the bulk of the literature on human capital focuses on the individual decision to invest in education and training, the present analysis sheds light on the role of contextual organizational factors - change in job complexity and in workplace practices that may support human capital formation.

\footnotetext{
${ }^{4}$ The OECD-PIAAC data set contains very accurately measured foundation skills in two domains (literacy and numeracy) but it does not contain a measure of the development of these skills over time.

${ }^{5}$ However, our measure will not account for the learning that has had an impact on workers' behaviour (and productivity) through the introjection of workplace norms (accepting diversity) or the outcomes of training aimed at enhancing motivation (Felstead, Gallie et al. 2010).
} 
The structure of the paper is as follows. Section 2 outlines the empirical model linking changes in job complexity and workplace changes to skills development. Section 3 describes the data. Section 4 presents the estimation results and their robustness to alternative model specifications. Section 5 offers some concluding remarks.

\section{The empirical model of workplace learning: the importance of job design and workplace characteristics}

The amount of learning afforded by the workplace is influenced/mediated by the way in which jobs are designed. If jobs consist of simple repetitive tasks, (a limited amount of) learning arises from repetition; through repetition the skills used to perform a given set of tasks are honed and perfected, resulting in a faster and more precise task execution. Complex jobs, on the other hand, place high demands on workers' skills for a variety of reasons (Wood 1986). Strain may derive from the number of tasks and number of decisions (problem solving) required (Wood 1986; Jovanovic and Nyarko 1995), from the uncertainty characterizing causal relationships or expected outcomes of choices, and often from the number or types of alternative courses of action (March and Simon 1958), from the informational needs linked to finding solutions to complex problems (Payne 1976; Campbell and Gingrich 1986; Hunter 1986; Sweller 1988; van Merriënboer and Sweller 2005), or from the need to use and integrate information from many different sources (Steinmann 1976).

These work-related challenges push workers out of their professional comfort zone, and learning will take place as workers draw on their knowledge, skills and abilities while searching for effective solutions (Anzai and Simon 1979; Eraut 2004; Berings, Poell et al. 2005; Pankhurst 2010). In the optimal learning situations, work-related situations pose a challenge to workers' skills and abilities, but the challenge is within reach and workers have the self-confidence needed to accept it (Csikszentmihalyi 1990; Latham 2012). Work itself becomes a source of learning (Jovanovic and Nyarko 1995), and mistakes can contribute to learning as well (Chialvo and Bak 1999; Simons and Ruijters 2008). Learning in the workplace requires workers to display a degree of initiative, a willingness to engage in learning activities, and a willingness to reflect on their actions and on the outcomes of their actions. Engaging in learning activities may in some cases be regarded as an inherent part of workmanship (Hager 2011). The learning process may be reinforced by contextual factors; i.e., feedback from managers and supervisors, but also from peers and colleagues (Kolb 1984; Eraut 2004; Kayes, Kayes et al. 2005). 
Organizations can affect the amount of learning taking place on the shop floor.

Organizations that regard human capital as an asset may promote and support learning (Rhoades and Eisenberger 2002; Illeris 2007; Fuller and Unwin 2011; Argote 2013) through a system of incentives that support workers' engagement in learning activities (Ardichvili 2011; Avey, Reichard et al. 2011), influence the workforce's attitude and commitment with respect to learning activities (Maurer, Weiss et al. 2003; Maurer, Lippstreu et al. 2008; Pierce and Maurer 2009; Hager 2011; Kyndt and Baert 2013), and ensure that the organization obtains an adequate return on the investment (Acemoglu and Pischke 1999; Acemoglu and Pischke 1999; Acemoglu and Pischke 2000). ${ }^{6}$

Organization characteristics can shape the availability of learning opportunities in the workplace through the way in which work processes are organized, the type of technology adopted, and the value given to learning, i.e. the socio-cultural importance of learning (Illeris 2011).

More precisely, the degree of skills development afforded by the workplace is influenced by three broad groups of factors:

1. individual workers' characteristics affecting the motivation to engage in learning activities (formal, informal or non-formal) and to learn;

2. job characteristics: jobs can be designed to encourage workers to draw on their skills and to provide them with learning opportunities in the form of complex problems to be solved and to confront workers with non-routine situations pushing them out of their comfort zone;

3. workplace characteristics influencing the availability of structured learning opportunities (training, coaching, and opportunities for professional exchanges between peers and colleagues) and support for the workers engaged in learning activities (Hackman and Oldham 1976; Parker and Ohly 2008; Fuller and Unwin 2011; Illeris 2011).

Though it is well known that workplace characteristics, job design and workers' characteristics affect learning, to the best of our knowledge there is no off-the-shelf model of how these factors interrelate that could be used to support the empirical analysis.

\footnotetext{
${ }^{6}$ This delicate ecosystem can be threatened by shocks affecting the stability of the employment contract such as downsizing (Lazear 2009). Organizations for which learning is important take appropriate measures to ensure that the retained workers (those who survive the downsizing) maintain a positive attitude towards learning (Tsai, Yen et al. 2007; Datta, Guthrie et al. 2010; Norman, Butler et al. 2013).
} 
Therefore, we assembled an empirical model with the explicit goal of linking selected background variables - chosen on the basis of a survey of the theoretical and empirical literature - to skills development. ${ }^{7}$

\section{Workplace Changes, workplace dynamism}

Organizations must change as they adopt new technologies and respond to competitive pressure. The launching of new product lines, improvement of products and production processes, and the adoption of new technologies or new organizational forms characterize dynamic workplaces. The SBTC approach maintains that technological changes lead to increased skill requirements that place increasing demands on workers' skills (Spitz-Oener 2006; Acemoglu and Autor 2011) and there is evidence that the same happens in organizations undergoing workplace changes (Caroli and Van Reenen 2001; Bresnahan, Brynjolfsson et al. 2002; Piva, Santarelli et al. 2005; Antonelli, Antonietti et al. 2010). Given the slow reaction of the education and training system in providing the skills required by technological and organizational changes, organizations will have to invest (at least initially) in the support of workers' skills development if they want to remain at the technological frontier (Goldin and Katz 2008; Bessen 2015). Because changing workplaces necessitate adaptation to new routines, it follows that workplace change is associated with training provision and on-the-job learning (Chen and Huang 2009; Antonelli, Antonietti et al. 2010; Neirotti and Paolucci 2013; Barba Aragón, Jiménez Jiménez et al. 2014).

\section{Changes in job complexity and skills development}

Learning in complex jobs will take place as workers mobilize their knowledge, skills, and competences to master the challenges that they meet while working (Anzai and Simon 1979; Eraut 2004; Berings, Poell et al. 2005; Pankhurst 2010). Increasing the degree of job complexity may push workers out of their comfort zone, confronting them with new situations and choices and, possibly difficult, problems. Workers will learn and develop their skill set as they seek to find satisfactory solutions to these new situations. In contrast, changes in the opposite direction, where jobs are transformed to consist of simple tasks performed routinely and repetitively in a rigidly codified way, and where only a limited number of skills are needed for successful performance, will rarely contain a learning stimulus (Pagano 2014;

\footnotetext{
${ }^{7}$ The literature review helped also to identify a weakness of the empirical model in the lack of measurement of the degree of workplace support for engaging in learning activities.
} 
Parker 2014). Therefore, the relationship between changes in job complexity and skills development is expected to be positive (Gibbs, Levenson et al. 2010).

\section{Attitude to learning}

Personal attitudes influence the likelihood that workers will actively seek to gain knowledge. Positive attitudes to learning will have a positive impact on the magnitude of the learning outcomes (Maurer, Weiss et al. 2003; Maurer, Lippstreu et al. 2008). We presume that a positive learning attitude will have a positive relationship with the degree of skill development. Participation in training and learning will take place more effectively when workers show commitment to training and learning (Maurer, Weiss et al. 2003; Maurer, Lippstreu et al. 2008; Kyndt and Baert 2013).

\section{Data and Measures}

The data used originated from a pan-European cross sectional survey on mismatch carried out by Cedefop in 2014: the European Skills and Job Survey (ESJS). The data set was compiled from interviews of employed workers (self-employed were excluded, employment status was self-reported) and in the 25 - 65 age bracket to minimize the impact of the steep learning curve taking place during school-to-work transition. ${ }^{8}$ The data set consisted of about 48,000 observations from 28 EU countries (Cedefop 2015).

Skills development was captured by a self-rated measure ranging from 0 to 10 (where 0 was anchored to "my skills decreased a lot" and 10 to "my skills increased a lot"). Only 5\% of the sample reported deterioration in their skills; $11 \%$ answered that their skills remained the same; while $84 \%$ of respondents reported some degree of positive skills development. The attitude to learning was measured by a single item tapping whether the respondents enjoyed learning for its own sake (higher values implying a more positive attitude to learning). About

\footnotetext{
${ }^{8}$ Interviews were carried out online in countries with a high internet penetration rate, using commercial panels. In countries with low internet penetration rates a mixed method was adopted, and a quota of the country sample was approached by telephone. Finally, in countries in which no commercial panels were available, only telephone interviews were carried out. The design effect of the sampling scheme adopted resulted in an increase in the standard error close to $40 \%$ with respect to the sampling error resulting from random sampling. However, the increase in the standard error resulting from accounting for the clustering of observations within countries had an even larger impact: the standard errors were 10 times larger than those obtained from treating the data as a simple random sample. The reports documenting the quality of the data and the design effect computations can be obtained from the author upon request. There was a slight difference in the questionnaires for the online and telephone modes. The online mode required less time to complete relative to the telephone interview (the interviewer did not have to read each question); consequently, the online questionnaire could accommodate a few more questions (i.e., the overall attitude towards learning scale instead of only 1 item included in the telephone interview).
} 
$80 \%$ of the sample reported a positive attitude to learning (in varying degrees). Workplace dynamism and work complexity changes were measured as latent variables (scales derived from survey questions). The workplace dynamic scale was obtained from items asking if changes in technologies, organisation, product lines and work procedures had been introduced. Change of complexity was measured by a scale consisting of three items capturing the changed variety and difficulty of tasks as well as the change of learning needs for the job. In general, jobs became more demanding over time; $80 \%$ of respondents reported an increase in the need to learn new things; $75 \%$ an increase in the difficulty of the tasks; and $78 \%$ an increase in the variety of tasks to be performed. The correlation between the changes in job complexity scale and the degree of skills development was 0.42 , providing prima facie evidence of the positive relationship between skills utilization and skills development.

Skills development can take place through various activities, and workers may have participated in more than one activity over the period of skills development. $64.6 \%$ of the workers with positive skills development had participated in training (that may have been held on the premises). However, the learning of $71.6 \%$ and $76.1 \%$ of the workers with positive skills development involved trial and error and self-study, and learning from colleagues and supervisors, respectively. Trial and error, self-study, learning from coworkers, colleagues, and supervisors are forms of learning that can be effectively deployed when jobs become increasingly complex.

\section{Estimation and robustness checks}

\subsection{Estimation results}

The regression model used to study the relationship between changes in job complexity and skills development consisted of the elements detailed in Section 2:

$$
\Delta S_{i}=\beta_{0}+\beta_{1} \Delta J C_{i}+\beta_{2} \Delta W P_{i}+\beta_{3} P C_{i}+\beta_{4} X_{i}+\varepsilon_{i}
$$

where $\Delta \mathrm{S}$ is the (self-reported) degree of change in skills, JC is the change in job complexity, WPC denotes the measure of workplace change, $\mathrm{PC}$ denotes personal characteristics and $\mathrm{X}$ is a vector of additional controls (country, industry, occupation dummies, firms' size, etc.). The regressors also included a dummy variable for training participation (if participants had not attended training in the last 12 months) and a variable for work experience (tenure, log of years with the current employer) that are clearly related to skills development. 
The results of the regression analysis are shown in Table $1 .^{9}$ The first model (column 1 in Table 1) shows the expected positive and significant relation between increases in job complexity and skills development. To give a better idea of the strength of the relationship, continuous variables have been standardized; the coefficient on the (standardized) increase in job complexity is 0.322 (with a standard error of 0.132): an increase of 1 standard deviation in the increase of job complexity is associated with an increase of 0.322 standard deviations in the degree of skill development.

The regression shows also the positive relationship between the workplace change scale and skills development.

The model shown in column 2 introduces training participation, or the lack thereof: workers not participating in training activities during the previous 12 months experienced a significantly lower degree of skills development compared to workers engaging in training (there is a positive relationship between participation in training activities and skills development). ${ }^{10}$ Accounting for training participation somewhat increases the size of the coefficient on the change in job complexity.

A positive attitude towards learning is also linked to the perceived degree of skills development. While a positive attitude to learning (a high score on the attitude to learning scale) does not directly lead to learning, it is very likely that workers with such a positive attitude will engage in learning activities (formal informal or non-formal, on-the-job or offthe-job, self-initiated or employer-initiated) more frequently than comparable individuals with a less positive attitude towards learning. Similarly, workers choosing a job for reasons related to skills (including personal interest) and for career reasons experience a positive degree of skill formation, but the skill formation experienced by those choosing their job for skill-related reasons is three times higher than that experienced by those choosing a job for career-related reasons.

Table 1: Regression results regarding the degree of skill development (robust standard errors in brackets, EU weighted data)

\footnotetext{
${ }^{9}$ The regression models in Table 1 are linear probability models. $99.8 \%$ of the expected values fall within the admissible [0 10$]$ interval.

${ }^{10}$ Interviewees taking the online version of the survey were also asked if workplace changes were supported by training. Workers receiving training whenever the workplace underwent a change had significantly higher skill development compared to workers who received training only for some of the changes. In turn, these workers experienced a larger degree of skill formation than workers who did not receive any training. These results are not shown but can be obtained from the authors upon request.
} 


\begin{tabular}{|c|c|c|c|}
\hline & \multicolumn{3}{|c|}{ Degree of skill development } \\
\hline & (1) & (2) & (3) \\
\hline \multirow[t]{2}{*}{ change in job complexity } & $0.380 * * *$ & $0.400 * * *$ & $0.371 * * *$ \\
\hline & {$[0.016]$} & [0.016] & {$[0.015]$} \\
\hline \multirow[t]{2}{*}{ index of workplace dynamism } & $0.144 * *$ & $0.126 * *$ & $0.0969 * *$ \\
\hline & {$[0.035]$} & {$[0.035]$} & {$[0.034]$} \\
\hline \multirow[t]{2}{*}{ enjoy learning for its own sake } & - & $0.0641 * * *$ & $0.0745^{* * *}$ \\
\hline & - & {$[0.007]$} & {$[0.007]$} \\
\hline \multirow[t]{2}{*}{ no training in past year } & - & $-0.292 * * *$ & $-0.260 * * *$ \\
\hline & - & {$[0.035]$} & {$[0.031]$} \\
\hline \multicolumn{4}{|l|}{ Mismatch Beginning current job } \\
\hline \multirow[t]{2}{*}{ Overskilled (reference group) } & - & - & 0 \\
\hline & - & - & [.] \\
\hline \multirow[t]{2}{*}{ Matched } & - & - & $0.429 * * *$ \\
\hline & - & - & {$[0.040]$} \\
\hline \multirow[t]{2}{*}{ Underskilled } & - & - & $0.774 * * *$ \\
\hline & - & - & {$[0.063]$} \\
\hline \multicolumn{4}{|l|}{ Career } \\
\hline \multirow[t]{2}{*}{ I have been promoted to a higher level position } & - & - & $0.197 * * *$ \\
\hline & - & - & {$[0.020]$} \\
\hline \multirow[t]{2}{*}{ I have moved to a different unit/department } & - & - & 0.0108 \\
\hline & - & - & {$[0.033]$} \\
\hline \multirow{3}{*}{$\begin{array}{l}\text { I have not been promoted or moved to another department } \\
\text { but the nature of my tasks and responsibilities has changed }\end{array}$} & & & \\
\hline & - & - & -0.0420 \\
\hline & - & - & {$[0.031]$} \\
\hline \multirow[t]{2}{*}{ I now have a lower-level position than when I started } & - & - & $-0.548 * * *$ \\
\hline & - & - & {$[0.105]$} \\
\hline \multirow{3}{*}{$\begin{array}{l}\text { No changes, my role has remained the same (reference } \\
\text { group) }\end{array}$} & & & \\
\hline & - & - & 0 \\
\hline & - & - & [.] \\
\hline \multicolumn{4}{|l|}{ Factors influencing decision to accept the job } \\
\hline \multirow[t]{2}{*}{ Job Security } & $0.0130 * *$ & 0.00848 & $0.0141 * *$ \\
\hline & {$[0.005]$} & {$[0.006]$} & {$[0.005]$} \\
\hline \multirow[t]{2}{*}{ Career-related reasons } & $0.0182 * *$ & $0.0224 * *$ & $0.0139 * *$ \\
\hline & {$[0.005]$} & {$[0.006]$} & {$[0.005]$} \\
\hline skills-related reasons & $0.0687 * * *$ & $0.0741 * * *$ & $0.0673 * * *$ \\
\hline
\end{tabular}




\begin{tabular}{|l|c|c|c|} 
& {$[0.006]$} & {$[0.006]$} & {$[0.005]$} \\
work-life balance & -0.0002 & -0.00627 & -0.0000852 \\
Tenure with current employer (log) & {$[0.005]$} & {$[0.005]$} & {$[0.005]$} \\
Personal Characteristics & $0.123 * * *$ & $0.170 * * *$ & $0.132 * * *$ \\
Highest Education level Attained & {$[0.022]$} & {$[0.024]$} & {$[0.022]$} \\
Job characteristics & YES & YES & YES \\
Industry & YES & YES & YES \\
Firm's Characteristics & YES & YES & YES \\
Previous Labour Market Position & YES & YES & YES \\
Mismatch in Previous Job & YES & YES & YES \\
Previous Occupation & YES & YES & YES \\
Personal Constraints & YES & YES & YES \\
Geographical Mobility & YES & YES & YES \\
Job Search and Prevailing Conditions on the Labour & YES & YES & YES \\
Market & YES & YES & YES \\
Occupation & YES & YES & YES \\
Country & YES & YES & YES \\
Constant & YES & YES & YES \\
\hline Number of Observations & $4.336 * * *$ & $4.805 * * *$ & $4.368 * * *$ \\
$\mathrm{R}^{2}$ & {$[0.354]$} & {$[0.357]$} & {$[0.372]$} \\
\hline
\end{tabular}

Firm's characteristics: type of organization (private or public), establishment size (number of employees). Job characteristics: full-time, type of contract (permanent, temporary or no contract at all), an indicator variable capturing whether the current job is the first job. Personal characteristics: age (in log), gender, born in the country, household composition. Highest educational qualification (3 levels: primary, upper-secondary and higher education). Previous labour market position (employed, self-employed, unemployed, long-term unemployed, out of the labour force, long-term out the labour force or in education), mismatch status in the previous job, an index of the degree of occupational change (if individuals held a job in the same occupation, in a similar occupation, or in a completely different occupation). Geographical Mobility: if the new job involved relocation to a different country, to a different region or no relocation at all. Personal constraints (family obligations): financial difficulties, family responsibility, owning own house. Job search effort (self-reported measure regarding whether many applications were made and time spent on job search) and prevailing labour market conditions at time of job search (perception of availability of vacancies for people with similar skills, if job offers were turned down and invitations to job interviews). Additional controls include: country (28 dummies), industry (16 dummies), and occupation (10 dummies). 
To study the stability of the relationship linking changes in job complexity to skills development, we adopted the following strategy: we monitored fluctuations in the regression coefficient on the construct measuring the change in job complexity induced by various changes (in the number and type of regressors or in the estimation sample) applied to the regression model. The results of this analysis are discussed hereafter (see also Table 1, column 3). ${ }^{11}$

\subsection{Robustness checks}

The robustness checks dealt with the impact on the estimates of three related issues: the effect of unobservable variables (for example, more able workers choosing to work in more complex jobs); the stability of the results, for example across countries and occupations; and the direction of causality (increases in skills leading to workers being assigned to more complex jobs or job complexity stimulating skill development).

\subsubsection{Unobservable characteristics}

Firstly, people generally stay in jobs that they like, and workers doing tasks that they like tend also to develop their skills. Since the data comprised retrospective information on skills and job complexity developments experienced by employed workers, the data collection method tended to inflate the relationship with the degree of skill development, especially in the subsample of workers with long job tenure. Secondly, workers experiencing a good initial match between their skills and those required by their job may have been hired by firms with good recruitment procedures to source the skills needed compared with workers who initially

\footnotetext{
${ }^{11}$ The focus of the analysis was on the relationship between changes in job complexity and changes in skills. We cannot rule out the presence of a level effect (the effect of job complexity on subsequent skills development) but we could not directly measure it because the questionnaire did not include a measure of initial job complexity, i.e., when workers joined the organization. To assess the likely impact of initial job complexity on the relationship between change in job complexity and skills development, we proceeded as follows: the current job complexity level was regressed on the change in job complexity and other regressors (same specification as in Table 1 column 3). The errors from this auxiliary regression were used to proxy the initial level of job complexity: positive errors denoted high initial job complexity, while negative errors denoted low initial job complexity. The relationship between change in job complexity and skills development was then estimated on the two sub-samples separately. The coefficient on the change in job complexity was 0.372 (with standard error 0.018 ) and 0.377 (with standard error 0.015) in the high and low initial job complexity subsample, respectively. This rough classification appears not to affect the coefficient on the change in job complexity. However, if we compare the coefficient on the change in job complexity in the subgroup with the lowest initial job complexity (the first quintile of the error distribution) with that obtaining in the subsample with the highest initial job complexity (the fifth quintile of the error distribution), the coefficient drops from 0.398 (with standard error 0.027 ) in the low initial job complexity level to 0.364 (with standard error 0.017) in the subsample with high initial job complexity level. While we cannot rule out that the job complexity level influences the relationship between change in job complexity and the skills development, the results presented above suggest that the effect is small.
} 
experienced a degree of skills mismatch. Firms with effective recruitment strategies to source skills may also adopt complex job design and have a learning culture that supports skills development. Finally, workers with a particularly positive attitude to learning may have selected themselves into complex jobs because of the learning opportunities offered by those jobs.

The magnitude of the impact of the aforementioned situations on the strength of the relationship between the changes in job complexity and the degree of skills development will be assessed below.

\section{Tenure}

Organizations learn about workers' skills and abilities by observing their performance over time (Gibbs 1995; Farber and Gibbons 1996; Prendergast 1999). Workers learn about the quality of their 'match' as well. A 'match' is an experience good; its value to the parties will be revealed over time. Learning and skills development in complex jobs signal a good match (high productivity) and influence the decision to stay. Good matches will tend to last longer than bad ones (Jovanovic 1979). These patterns of learning are re-enacted every time that workers experience a change of job (as consequence of vertical mobility - a promotion - or as a consequence of horizontal mobility - job rotation).

We addressed this issue by estimating the regression model (without tenure) on two subsamples: workers with tenure of less than 5 years and workers with longer tenure. The coefficient on the change in job complexity was 0.38 in the former group and 0.39 in the latter. When tenure was included in the two models, the coefficient on the job complexity change in the sub-sample with short job tenure changed to 0.37 (while the coefficient in the long job tenure sample remained unchanged). These findings suggest that the effect of changes in job complexity on skills development is not significantly influenced by tenure. Interestingly, however, the effect of tenure on skills development was much stronger in the short tenure sub-sample (coefficient 0.18 with a standard error of 0.03 ) than in the long tenure sub-sample (coefficient 0.05 with standard error 0.04). It appears that a large part of learning-by-doing takes place in the first five years of employment. 


\section{Initial mismatch}

Given the degree of choice in the way tasks may be bundled in complex job designs, and given the varying level of autonomy warranted by complex jobs across firms, ${ }^{12}$ jobs with complex design form a particularly heterogeneous group. Since a large number of contingencies may arise in complex jobs, it is difficult for organizations to provide, ex-ante, realistic job previews to job applicants. The problem is compounded by the heterogeneity characterizing workers' skills and abilities. ${ }^{13}$ Therefore, an initial misalignment between workers' skills and the requirements of jobs may be the expected outcome of job search and recruitment actions (Lazear 2009). ${ }^{14}$ If it is not possible to find individuals possessing all the desirable attributes, some degree of compromise is generally required. When confronted with the choice between subsets of personal attributes in prospective employees, the prevailing view among human resource professionals is to select those with the right personality traits (those fitting the job environment) and use training to build the (technical) skills that they lack (to meet the job's requirements). This practice implicitly acknowledges the key role of workplaces in skills formation when the balance between workers' skills and job demands (in

\footnotetext{
${ }^{12}$ Organizations are heterogeneous in the ways that they adopt management practices, design jobs and make use of workers' skills (Bloom and Van Reenen 2007; Bloom and Van Reenen 2010; Bloom and Van Reenen 2011; Bloom, Genakos et al. 2012; Bloom, Sadun et al. 2012; Bloom, Lemos et al. 2014). Jobs can be designed in various ways and the job design will have an impact on how workers will have to deploy their skills in order to be effective: some organizations bundle a variety of skills into complex jobs, while other break production down into precisely described and rather narrowly defined tasks, which then become jobs (Korpi and Tåhlin 2009). The way in which organizations make use of workers' skills is affected by the technology adopted and how the production process is organized (Bresnahan, Brynjolfsson et al. 2002). ${ }^{12}$ Finally, job design will be influenced by organizations' culture, business and product strategies (Youndt, Snell et al. 1996; Kaufman 2010; Kaufman 2010; Boxall and Purcell 2011; Kaufman and Miller 2011; Sung and Ashton 2015).

${ }^{13}$ Workers' knowledge, skills, ability and their propensity to engage in desirable behaviours (from the point of view of the organization) are not directly observable. Recruiters rely on coarse measures of knowledge and ability (educational qualifications) and try to assess the presence of desirable but hard to measure personal characteristics with other techniques. Organisations with modern workplaces spend a great deal of time on evaluating the fit between prospective workers and the company culture. The time and resources devoted to personnel selection testify to the importance of allocating the right people to the right jobs for the economic success of organizations. The crux of the selection process lies in uncovering workers' skills (KSAs, knowledge, skills, competences, and abilities) so that these can be effectively matched to the job's demands (Ployhart and Schneider 2012). The bundle of competences, attitudes and skills required by jobs (job design) needs to be embodied in the right worker and not in just any worker (Kristof-Brown, Zimmerman et al. 2005).

${ }^{14}$ The European Skills and Jobs Survey reports that $24 \%$ of workers did not possess the full set of skills needed to perform their jobs when they joined their current organization. Most of these workers, however, developed the skills necessary to be proficient in their jobs (Cedefop 2015). Moreover, the proportion of underskilled workers jumped to $31 \%$ among those entering their first job. When new workers are directly hired from education (possibly with an intervening spell of unemployment) they may have the technical and theoretical knowledge, but they often lack the mind-set as well as applied knowledge and the soft skills (attitudes) needed to function properly in the workplace (Eurobarometer 2010; Hettich and Landrum 2014).School leavers are an important pool of applicants for organizations. Experienced workers are hard to recruit for a variety of reasons: they can command higher wages, and they are less mobile (they often own their homes and are more likely to have partners with jobs and a family).
} 
terms of skills) can change over time. ${ }^{15}$ Consequently, the degree of skill development may depend on the initial distance between a job's skill requirements and a worker's skill endowment: underskilled workers will have greater growth potential than workers whose skills match or exceed the job's skill requirements.

The inclusion of the initial match conditions (together with variables measuring career progress) in the regression model - see the model in the last column of Table 1 - delivers the expected results: the coefficient on the change in job complexity drops somewhat (by about $10 \%$ ); the underskilled workers and those with skills matching their jobs record average increases in the degree of skill development higher than those of overskilled workers. The self-assessed increment in skills is largest in the group of underskilled workers (van der Velden and Verhaest forthcoming).

However, the strength of the relationship between the change in job complexity and skill development displays the oppositepattern: it is strongest among those who were overskilled when they joined the current employer, intermediate among those whose skills were matched, and weakest among those who were underskilled (the coefficients on the change in job complexity in the three groups are $0.406,0.380$, and 0.266 ; the standard errors are 0.020 , 0.012 , and 0.036 , respectively).

All in all, workers that start in jobs for which they are overskilled may suffer from a slow skill development in the absence of stimuli deriving from the complexity of the job; however, when stimulated by increasing job complexity, they display the fastest rate of skill development.

\section{Attitude to learning}

The effects of changes in job complexity on workers' skills development may arise from workers with a positive attitude towards learning who self-select into such jobs. To check the empirical content of this contingency, we re-ran the models on subsamples split according to whether or not workers had a strong positive attitude to learning (a score above 5, and then above 7, on the question "I like to learn for its own sake", a proxy for a positive attitude to learning). The coefficient on the change in job complexity did not change appreciably in the two sub-samples characterized by a high and low attitude to learning (the coefficient is 0.37

\footnotetext{
${ }^{15}$ Many organisations routinely review skill needs in their workforce: for example, $72 \%$ of EU companies review internal skill needs (Eurofund 2010).
} 
in the subsample scoring 5 or less on the attitude to learning scale and 0.38 in the subsample of workers scoring more than 5). ${ }^{16}$

The last robustness check included a cross-effect among the change in job complexity and tenure, attitude to learning, and initial mismatch (these were added to model 3 in Table 2). The first two interaction effects were not significant: the coefficients on the interaction with tenure and attitude to learning were -0.007 and -0.003 with standard error 0.010 and 0.03 , respectively; they were jointly not significant, the $F$ statistic was $F(2,27)=1.37$ with a p-value of $0.272 .{ }^{17}$ Interacting the change in job complexity with the initial skills mismatch returned the expected results: compared to workers who began in jobs for which they were overskilled, change in job complexity was associated with less skill development (coefficient -0.058 with a standard error 0.023 ) for workers who started out in a matched job, and even less skill development (coefficient -0.164 with a standard error of 0.018 ) for the workers who started out as underskilled.

\subsubsection{Other robustness checks: country and occupation}

The empirical analysis uncovered a positive relationship between increases in the job complexity scale and skills development on using the sample obtained by pooling observations across EU countries. To buttress the general validity of the result, the model was estimated by country and occupation (separately). Figure 1 shows that, by and large, the coefficient on the change in job complexity in the various countries has the same order of magnitude as the one estimated on the pooled sample. Statistically significant deviations from the coefficient obtained from the pooled sample are observed only in Italy and Lithuania.

\section{FIGURE 1 ABOUT HERE}

The relationship between increases in job complexity and skills development appears to be also stable across occupations: see Figure 2. Consequently, the relationship between increased job complexity and skills development can be considered as general, and as applying across diverse institutional settings (imperfectly represented by the national context) and to very different occupational groups.

\footnotetext{
${ }^{16}$ We also split the sample according to whether the job was chosen because it fitted the worker's skills or interests. The results were identical.

${ }^{17}$ We also allowed for the attitude to learning to affect the strength of the relationship between participation in training and skill development. The effect of training on skills development is strongly affected by the attitude to learning: the more positive the attitude to learning, the stronger the effect of training participation on skills development. The coefficient on training participation becomes non-significant.
} 


\section{FIGURE 2 ABOUT HERE}

\subsubsection{Endogeneity issues: career and skills development}

It is hard to give a causal interpretation to the positive relationship between job complexity and skill development because the two are assessed simultaneously. Nonetheless, longitudinal studies and meta-analyses have found that job characteristics are antecedents of many jobrelated outcomes (Mathieu and Zajac 1990; de Jonge, Dormann et al. 2001; De Lange, Taris et al. 2004; Saks 2006; ter Doest and De Jonge 2006; Humphrey, Nahrgang et al. 2007; Crawford, LePine et al. 2010). ${ }^{18}$

The association between skill development and changes in job complexity may be the result of career progression: job complexity increases as workers are promoted to higher-level positions, and this process is associated with a process of skills development. Table 1 (column 3) shows that including the career development variables in the regression did not change the sign and size of the effect of changes in job complexity on the degree of skills development. Moreover, the coefficient on the change in job complexity did not change when we restricted the sample to those workers who did not change job title or tasks during the period considered (the coefficient on the change in job complexity was 0.378 with a standard error of 0.017). All in all, these analyses suggest that the relationship between changes in job complexity and skill development may not be driven by career progression.

Recently, the literature on HRM has advanced a more dynamic concept of job design that sees workers as playing an active role in shaping (crafting) the scope of their jobs (Berg, Dutton et al. 2013; Nielsen 2013). We do not think that this approach significantly undermines the validity of our analysis for three reasons. First, also the literature on job

\footnotetext{
${ }^{18}$ To support our claim we tentatively offer an IV approach that relies on the assumption that workplace changes affect skills development through the challenges and the learning opportunities offered by increased job complexity (while controlling for participation in training). Table 1 shows that workplace dynamism has a positive impact on skills development. However, the coefficient is not stable across countries and occupations (the coefficient on dynamic workplace is positive significant in 5 countries, positive non-significant in 15 countries and negative non-significant in 8 countries; the coefficient on workplace dynamism is positive significant in only 2 occupations). This suggests that being in a dynamic workplace may have only a distal effect on, or an indirect relationship with, skills development; workplace dynamism may affect workers' skills through increased opportunities for on-the-job learning (or in training opportunities), the changes introduced in terms of products, processes and technologies foster learning through their impact on workers' roles and tasks and their impact on the way that tasks are combined into jobs. Ultimately, it is how jobs are designed that determines the amount of learning afforded in the job and skills development. When workplace changes induce exogenous changes in job complexity, these have a positive impact on skills development of the same order of magnitude as the one in Table 1: the coefficient on change in job complexity is 0.46 (with a standard error of 0.03 ). The first step regression confirms the relevance of the instrument: workplace changes induce a positive change in job complexity. The coefficient on workplace change is 1.05 (with a standard error of 0.048 ), a t-statistic of 21.32 and an F-statistic of 454.6.
} 
crafting acknowledges that job design must be regarded as the starting point of the jobcrafting process and that the changes are at the margin (Tims and Bakker 2010; Tims, Bakker et al. 2012; Berg, Dutton et al. 2013). Second, some personal characteristics have been associated with an inclination to craft own jobs, while skills (proxied by cognitive ability) have been found to have no significant correlation with the likelihood of engaging in the jobcrafting process and its extent (Lyons 2008). Third, the human resource management literature has characterised workers' inclination to personalize the set of tasks that they perform though various constructs: commitment (Green 2008), extra role behaviour (assuming additional tasks outside the worker's role in the organization) (Van Dyne, Cummings et al. 1995), organizational citizenship behaviour - assuming additional tasks to help colleagues - (Organ 1997; Organ, Podsakoff et al. 2006), and contextual performance (Borman and Motowidlo 1993; Motowidlo and Van Scotter 1994); a cursory review of the literature (mainly based on the US labour market) reveals that personality traits are generally linked to these behaviours rather than to skills (Morgeson, Delaney-Klinger et al. 2005; Bakker, Tims et al. 2012).

\section{Conclusions}

The paper has investigated the importance of skills development in workplaces. Skills develop when workers engage in meaningful learning activities (i.e., training or meaningful on-the-job learning). Changes in job complexity may expose workers to new challenges and thus foster learning and skills development. The empirical analysis showed a robust and stable relationship between changes in job complexity and workers' skills development across national and occupational contexts.

The results also confirmed the significance of attitudinal and motivational dispositions for skill formation. Workers who give importance to skills utilization when choosing their job and workers with a positive attitude to learning experience large changes in their skills set. Consequently, the inclusion of additional individual characteristics, such as personality traits, is likely to improve the empirical model (Maurer, Lippstreu et al. 2008).

The analysis also uncovered an interesting aspect regarding the skill development of overskilled workers: workers starting out in jobs for which they are overskilled tend to report small skill development in the absence of stimuli deriving from job complexity. However, 
when stimulated by increasing job complexity, they report very large skill development (larger than that reported by workers starting out underskilled or matched).

The analysis also suggests that organizational characteristics have an impact on the amount of skills development. The results suggest that workplace dynamism is, on average, skill-biased. Although, the direct relationship between workplace dynamism and skill development is not stable across countries and occupations, workplace changes are also accompanied by increased job complexity, and through this channel they also support skills development. In fact, increases in job complexity are positively and robustly linked with skills development (Hackman and Oldham 1976; Oldham and Hackman 2010). Also training provision has a positive impact on the degree of skills development, especially among workers with a positive attitude to learning.

Finally, given the robust relationship linking increasing job complexity and skills formation in the workplace, the analysis suggests that the promotion of skills utilization in organizations may be accompanied by skills development. Complex job design tends to put strain on workers' skills but, at the same time, it provides scope and stimulus for skills development; this result has practical implications for organizations in terms of productivity gains.

From a policy point of view, the results suggest that supply-side policies aimed at increasing workers' skills should be complemented by demand-side policies promoting skills utilization through the adoption of complex job design in workplaces. Clearly, the policy levers that could be used to improve skills utilization (the adoption of complex job design and the implementation of the accompanying human resource practices) will differ across organizational contexts, depending on how skills support organizational success. The importance and the role of workers' skills for organizational success will be affected by organizational characteristics such as: organizational culture and goals, technology, product market approach, and business strategy. However, the ways in which organizations utilize skills is an under-researched area in economics. Consequently, the empirical model could be further improved by the inclusion of contextual variables capturing organizational efforts aimed at supporting workplace learning: continuous training provision, cooperative industrial relations, peer learning among colleagues and supervisors, the importance of applicants' characteristics such as trainability and learning attitude in recruitment, and the degree of support from managers and colleagues for training participation. Ultimately, there is a need 
for better understanding of the various ways in which skills can foster organizational success.

We leave this important topic for future research.

\section{References}

Acemoglu, D. and D. Autor (2011). Skills, Tasks and Technologies: Implications for Employment and Earnings. Handbook of Labor Economics. D. Card and O. Ashenfelter. Amsterdam, Elsevier. Volume 4, Part B: 1043-1171.

Acemoglu, D. and J.-S. Pischke (1999). "Beyond Becker: Training in Imperfect Labour Markets." The Economic Journal 109(453, Features): F112-F142.

Acemoglu, D. and J.-S. Pischke (1999). "The Structure of Wages and Investment in General Training." Journal of Political Economy 107(3): 539-572.

Acemoglu, D. and J.-S. Pischke (2000). "Certification of training and training outcomes." European Economic Review 44(4-6): 917-927.

Antonelli, G., R. Antonietti, et al. (2010). "Organizational change, skill formation, human capital measurement: evidence from Italian manufacturing firms." Journal of Economic Surveys 24(2): 206-247.

Anzai, Y. and H. A. Simon (1979). "The theory of learning by doing." Psychological Review: 124-140.

Ardichvili, A. (2011). "Invited reaction: Meta-analysis of the impact of psychological capital on employee attitudes, behaviors, and performance." Human Resource Development Quarterly 22(2): 153-156.

Argote, L. (2013). Organizational Learning. Creating, Retaining and Transferring Knowledge. New York, Springer.

Argote, L. and E. Miron-Spektor (2011). "Organizational Learning: From Experience to Knowledge." Organization Science 22(5): 1123-1137.

Arrow, K. J. (1962). "The economic consequences of learning by doing." The Review of Economic Studies 29(3): 155 - 173.

Avey, J. B., R. J. Reichard, et al. (2011). "Meta-analysis of the impact of positive psychological capital on employee attitudes, behaviors, and performance." Human Resource Development Quarterly 22(2): 127-152.

Awano, G., M. Franklin, et al. (2010). "Measuring investment in intangible assets in the UK: results from a new survey." Economic \& Labour Market Review 4(7): 66-71.

Bakker, A. B., M. Tims, et al. (2012). "Proactive personality and job performance: The role of job crafting and work engagement." Human Relations 65(10): 1359-1378.

Barba Aragón, M. I., D. Jiménez Jiménez, et al. (2014). "Training and performance: The mediating role of organizational learning." BRQ Business Research Quarterly 17(3): 161-173.

Barney, J. B. (2001). "Resource-based theories of competitive advantage: A ten-year retrospective on the resource-based view." Journal of Management 27(6): 643-650.

Beaudry, P., D. A. Green, et al. (2013). "The Great Reversal in the Demand for Skill and Cognitive Tasks." National Bureau of Economic Research Working Paper Series No. 18901 (published as Paul Beaudry, David A. Green, Ben Sand. "The Great Reversal in the Demand for Skill and Cognitive Tasks," in Alexandre Mas and David Card, organizers, "The Labor Market in the Aftermath of the Great Recession" Journal of Labor Economics (University of Chicago Press) (2015)).

Berg, J. M., J. E. Dutton, et al. (2013). Job Crafting and the meaning of work. Purpose and Meaning in the Workplace. B. J. Dik, Z. S. Byrne and M. F. Steger, American Psychological Association.

Berings, M. G. M. C., R. F. Poell, et al. (2005). "Conceptualizing On-the-Job Learning Styles." Human Resource Development Review 4(4): 373-400.

Besanko, D., U. Doraszelski, et al. (2014). "The Economics of Predation: What Drives Pricing When There Is Learning-by-Doing?" 104(3): 868-897. 
Bessen, J. (2015). Learning by doing. The real conncetion between innovation, wages, nad wealth. New Heaven, Yale University Press.

Blair, M. M. (2011). An Economic Perspective on the Notion of "Human Capital". The Oxford Handbook of Human Capital. A. Burton-Jones and J.-C. Spender. Oxford, Oxford University Press.

Bloom, N., C. Genakos, et al. (2012). "Management Practices Across Firms and Countries." The Academy of Management Perspectives 26(1): 12-33.

Bloom, N., R. Lemos, et al. (2014). "The new empirical economics of management." Journal of the European Economic Association 12(4): 835-876.

Bloom, N., R. Sadun, et al. (2012). "The organization of firms across countires." The Quarterly Journal of Economics 127(4): 1663-1705.

Bloom, N. and J. Van Reenen (2007). "Measuring and Explaining Management Practices Across Firms and Countries." The Quarterly Journal of Economics 122(4): 1351-1408.

Bloom, N. and J. Van Reenen (2010). "Why Do Management Practices Differ across Firms and Countries?" The Journal of Economic Perspectives 24(1): 203-224.

Bloom, N. and J. Van Reenen (2011). Human Resource Management and Productivity. Handbook of Labor Economics. C. David and A. Orley, Elsevier. Volume 4, Part B: 1697-1767.

Borman, W. C. and S. J. Motowidlo (1993). Expanding the criterion domain to include elements of contextual performance. Personnel Selection in Organizations. N. Schmitt and W. C. Borman. San Francisco, Jossey-Bass.

Boxall, P. and J. Purcell (2011). Strategy and Human Resource Management. New York, Palgrave Macmillan

Bresnahan, T. F., E. Brynjolfsson, et al. (2002). "Information Technology, Workplace Organization, and the Demand for Skilled Labor: Firm-Level Evidence." The Quarterly Journal of Economics 117(1): 339-376.

Brown, T. A. (2006). Confirmatory factor analysis for applied research. New York, The Guilford Press.

Campbell, D. J. and K. F. Gingrich (1986). "The interactive effects of task complexity and participation on task performance: A field experiment." Organizational Behavior and Human Decision Processes 38(2): 162-180.

Caroli, E. and J. Van Reenen (2001). "Skill-Biased Organizational Change? Evidence from A Panel of British and French Establishments." The Quarterly Journal of Economics 116(4): 1449-1492.

Cedefop (2015). Skills, qualifications and jobs in the EU: the making of a perfet match? Evidence from Cedefop's European Skills and Jobs Survey. Luxembourg, Publications Office.

Chen, C.-J. and J.-W. Huang (2009). "Strategic human resource practices and innovation performance - The mediating role of knowledge management capacity." Journal of Business Research 62(1): 104-114.

Chialvo, D. R. and P. Bak (1999). "Learning from mistakes." Neuroscience 90(4): 1137-1148.

Coff, R. and D. Kryscynski (2011). "Invited Editorial: Drilling for Micro-Foundations of Human CapitalBased Competitive Advantages." Journal of Management 37(5): 1429-1443.

Colquitt, J. A., J. A. LePine, et al. (2000). "Toward an integrative theory of training motivation: A meta-analytic path analysis of 20 years of research." Journal of Applied Psychology 85(5): 678-707.

Crawford, E. R., J. A. LePine, et al. (2010). "Linking job demands and resources to employee engagement and burnout: A theoretical extension and meta-analytic test." Journal of Applied Psychology 95(5): 834-848.

Csikszentmihalyi, M. (1990). Flow: The Psychology of Optimal Experience. New York, Harper and Row.

Datta, D. K., J. P. Guthrie, et al. (2010). "Causes and Effects of Employee Downsizing: A Review and Synthesis." Journal of Management 36(1): 281-348. 
de Jonge, J., C. Dormann, et al. (2001). "Testing reciprocal relationships between job characteristics and psychological well-being: A cross-lagged structural equation model." Journal of Occupational and Organizational Psychology 74(1): 29-46.

De Lange, A. H., T. W. Taris, et al. (2004). "The relationships between work characteristics and mental health: examining normal, reversed and reciprocal relationships in a 4-wave study." Work \& Stress 18(2): 149-166.

Eraut, M. (2004). "Informal learning in the workplace." Studies in Continuing Education 26(2): 247273.

Eurobarometer (2010). Employers' perception of graduate employability.

Eurofund (2010). European Company Survey 2009. Luxembourg, Publication Office of the European Union.

Farber, H. S. and R. Gibbons (1996). "Learning and Wage Dynamics." The Quarterly Journal of Economics 111(4): 1007-1047.

Felstead, A., D. Gallie, et al. (2010). "Employee involvement, the quality of training and the learning environment: an individual level analysis." The International Journal of Human Resource Management 21(10): 1667-1688.

Fuller, A. and L. Unwin (2011). Workplace learning and the organization. The sage handbook of workplace learning. M. Malloch, L. Cairns, K. Evans and B. N. O'Connor. London, Sage.

Gibbs, M. (1995). "Incentive compensation in a corporate hierarchy." Journal of Accounting and Economics 19(2-3): 247-277.

Gibbs, M., A. Levenson, et al. (2010). Why are jobs designed the way they are? Jobs, Training, and Worker Well-being. S. W. Polachek and K. Tatsiramos. London, Emerald Group. 30: 107-154.

Goldin, C. and L. F. Katz (2008). The race between education and technology. Cambridge, Harvard University Press.

Green, F. (2008). "Leeway for the Loyal: A Model of Employee Discretion." British Journal of Industrial Relations 46(1): 1-32.

Green, F. (2013). Skills and skilled work: an economic and social analysis. Oxford, Oxford University Press.

Hackman, R. J. and G. R. Oldham (1976). "Motivation through the design of work: test of a theory." Organizational Behavior and Human Performance 16(2): 250-279.

Hager, P. (2011). Theories of workplace learning. The sage handbook of workplace learning. $M$. Malloch, L. Cairns, K. Evans and B. N. O'Connor. London, Sage.

Hall, R. (1992). "The strategic analysis of intangible resources." Strategic Management Journal 13(2): 135-144.

Heckman, J. J. (2000). "Policies to foster human capital." Research in Economics 54(1): 3-56.

Hettich, P. I. and E. R. Landrum (2014). Your Undergraduate Degree in Psychology. From College to Career. Thousand Oakes, Sage Publications.

Hult, G. T. M., D. J. Ketchen, et al. (2005). "Market orientation and performance: an integration of disparate approaches." Strategic Management Journal 26(12): 1173-1181.

Humphrey, S. E., J. D. Nahrgang, et al. (2007). "Integrating motivational, social, and contextual work design features: A meta-analytic summary and theoretical extension of the work design literature." Journal of Applied Psychology 92(5): 1332-1356.

Hunter, J. E. (1986). "Cognitive ability, cognitive aptitudes, job knowledge, and job performance." Journal of Vocational Behavior 29(3): 340-362.

Ichniowski, C., D. I. Levine, et al. (2000). The American workplace. Skills, compensation, and emplyee involvment. Cambridge, Cambridge University Press.

Illeris, K. (2007). How we learn. Learning and non-learning in school snd beyond. New York, Routledge.

Illeris, K. (2011). Workplaces and learning. The sage handbook of workplace learning. M. Malloch, L. Cairns, K. Evans and B. N. O'Connor. London, Sage. 
Jeon, K. S. and K.-N. Kim (2012). "How do organizational and task factors influence informal learning in the workplace?" Human Resource Development International 15(2): 209-226.

Jovanovic, B. (1979). "Job Matching and the Theory of Turnover." Journal of Political Economy 87(5): 972-990.

Jovanovic, B. and Y. Nyarko (1995). "A Bayesian Learning Model Fitted to a Variety of Empirical Learning Curves." Brookings Papers on Economic Activity. Microeconomics: 247-305.

Kahneman, D. (2011). Thinking, Fast and Slow. New York, Farrar, Straus and Giroux.

Kaufman, B. E. (2010). "SHRM Theory in the Post-Huselid Era: Why It Is Fundamentally Misspecified." Industrial Relations: A Journal of Economy and Society 49(2): 286-313.

Kaufman, B. E. (2010). "A theory of the firm's demand for HRM practices." The International Journal of Human Resource Management 21(5): 615-636.

Kaufman, B. E. and B. I. Miller (2011). "The Firm's Choice of Hrm Practices: Economics Meets Strategic Human Resource Management." Industrial \& Labor Relations Review 64(3): 526 557.

Kayes, A. B., D. C. Kayes, et al. (2005). "Experiential learning in teams." Simulation \& Gaming 36(3): 330-354.

Ketchen, D. J., G. T. M. Hult, et al. (2007). "Toward greater understanding of market orientation and the resource-based view." Strategic Management Journal 28(9): 961-964.

Kirby, J. R., C. Knapper, et al. (2010). "Development of a scale to measure lifelong learning." International Journal of Lifelong Education 29(3): 291-302.

Klenow, P. J. (1998). "Learning Curves and the Cyclical Behavior of Manufacturing Industries." Review of Economic Dynamics 1(2): 531-550.

Kolb, D. (1984). Experiential Learning as the Science of Learning and Development. Englewood Cliffs, NJ, Prentice Hall.

Korpi, T. and M. Tåhlin (2009). A tale of two distinctions: The significance of job requirements and informal workplace training for the training gap, Stockholm University.

Kristof-Brown, A. L., R. D. Zimmerman, et al. (2005). "Consequences of individuals' fit at work: a meta-analysis of person-job, person-organization, person-group, and person-supervisor fit." Personnel Psychology 58(2): 281-342.

Kyndt, E. and H. Baert (2013). "Antecedents of Employees' Involvement in Work-Related Learning: A Systematic Review." Review of Educational Research 83(2): 273-313.

Latham, G. P. (2012). Work Motivation. History, Theory, Research, and Practice. Thousand Oakes, Sage.

Lazear, E. P. (2009). "Firm-Specific Human Capital: A Skill-Weights Approach." Journal of Political Economy 117(5): 914-940.

Levitt, S. D., J. A. List, et al. (2013). "Toward an Understanding of Learning by Doing: Evidence from an Automobile Assembly Plant." Journal of Political Economy 121(4): 643-681.

Luthans, F., C. M. Youssef, et al. (2006). Psychological Capital: Developing the Human Competitive Edge. Oxford, Oxford University Press

Lyons, P. (2008). "The Crafting of Jobs and Individual Differences." Journal of Business and Psychology 23(1-2): 25-36.

March, J. G. and H. A. Simon (1958). Organizations. Oxford, B; ackwell Publishers.

Marsick, V. J. (2013). "The Dimensions of a Learning Organization Questionnaire (DLOQ): Introduction to the Special Issue Examining DLOQ Use Over a Decade." Advances in Developing Human Resources 15(2): 127-132.

Marsick, V. J. and K. E. Watkins (2003). "Demonstrating the Value of an Organization's Learning Culture: The Dimensions of the Learning Organization Questionnaire." Advances in Developing Human Resources 5(2): 132-151.

Mathieu, J. E. and D. M. Zajac (1990). "A review and meta-analysis of the antecedents, correlates, and consequences of organizational commitment." Psychological Bulletin 108(2): 171-194. 
Maurer, T. J., M. Lippstreu, et al. (2008). "Structural model of employee involvement in skill development activity: The role of individual differences." Journal of Vocational Behavior $\mathbf{7 2 :}$ 336-350.

Maurer, T. J., E. M. Weiss, et al. (2003). "A Model of Involvement in Work-Related Learning and Development Activity: The Effects of Individual, Situational, Motivational, and Age Variables." Journal of Applied Psychology 88(4): 707-724.

Molloy, J. C., C. Chadwick, et al. (2011). "Making Intangibles "Tangible" in Tests of Resource-Based Theory: A Multidisciplinary Construct Validation Approach." Journal of Management 37(5): 1496-1518.

Morgeson, F. P., K. Delaney-Klinger, et al. (2005). "The Importance of Job Autonomy, Cognitive Ability, and Job-Related Skill for Predicting Role Breadth and Job Performance." Journal of Applied Psychology 90(2): 399-406.

Motowidlo, S. J. and J. R. Van Scotter (1994). "Evidence that task performance should be distinguished from contextual performance." Journal of Applied Psychology 79(4): 475-480.

Neirotti, P. and E. Paolucci (2013). "Why do firms train? Empirical evidence on the relationship between training and technological and organizational change." International Journal of Training and Development 17(2): 93-115.

Nielsen, K. (2013). "How can we make organizational interventions work? Employees and line managers as actively crafting interventions." Human Relations 66(8): 1029-1050.

Norman, P. M., F. C. Butler, et al. (2013). "Resources Matter: Examining the Effects of Resources on the State of Firms Following Downsizing." Journal of Management 39(7): 2009-2038.

Oldham, G. R. and J. R. Hackman (2010). "Not what it was and not what it will be: The future of job design research." Journal of Organizational Behavior 31(2-3): 463-479.

Organ, D. W. (1997). "Organizational Citizenship Behavior: It's Construct Clean-Up Time." Human Performance 10(2): 85-97.

Organ, D. W., P. M. Podsakoff, et al. (2006). Organizational Citizenship Behavior. Its nature, antecedents, and consequences. Thousand Oaks, Sage Publications.

Osterman, P. and B. Shulman (2011). Good Jobs America: Making Work Better for Everyone. New York, Russell Sage Foundation.

Pagano, U. (2014). "The crisis of intellectual monopoly capitalism." Cambridge Journal of Economics.

Pal, R., H. k. Torstensson, et al. (2014). "Antecedents of organizational resilience in economic crises: an empirical study of Swedish textile and clothing SMEs." International Journal of Production Economics 147(Part B): 410-428.

Pankhurst, K. V. (2010). "Learning by experience, work and productivity: theory and empirical evidence." Journal of Vocational Education \& Training 62(2): 103-122.

Parker, S. K. (2014). "Beyond Motivation: Job and Work Design for Development, Health, Ambidexterity, and More." Annual Review of Psychology 65(1): 661-691.

Parker, S. K. and S. Ohly (2008). Designing motivating jobs: an expanded framework for linking work characteristics and motivation. Work Motivation. Past Present and Future. R. Kanfer, G. Chen and R. D. Pritchard. New York, Routledge: 233 - 284.

Payne, J. W. (1976). "Task complexity and contingent processing in decision making: An information search and protocol analysis." Organizational Behavior and Human Performance 16(2): 366387.

Pierce, H. R. and T. J. Maurer (2009). "Linking employee development activity, social exchange and organizational citizenship behavior." International Journal of Training and Development 13(3): 139-147.

Piva, M., E. Santarelli, et al. (2005). "The skill bias effect of technological and organisational change: Evidence and policy implications." Research Policy 34(2): 141-157.

Ployhart, R. E. and T. P. Moliterno (2011). "Emergence of the Human Capital Resource: A Multilevel Model." Academy of Management Review 36(1): 127-150. 
Ployhart, R. E. and B. Schneider (2012). The social and organizational context of personnel selection. The Oxford handbook of personnel assessment and selection. N. Schmitt. New york, Oxford University Press: 48 - 67.

Pouliakas, K. and G. Russo (2015). Heterogeneity of Skill Needs and Job Complexity: Evidence from the OECD PIAAC Survey, IZA Discussion Paper No 9392.

Prendergast, C. (1999). "The Provision of Incentives in Firms." Journal of Economic Literature 37(1): 7-63.

Rhoades, L. and R. Eisenberger (2002). "Perceived organizational support: A review of the literature." Journal of Applied Psychology 87(4): 698-714.

Saks, A. M. (2006). "Antecedents and consequences of employee engagement." Journal of Managerial Psychology 21(7): 600-619.

Simons, P. R.-J. and M. C. P. Ruijters (2008). "Varieties of work related learning." International Journal of Educational Research 47(4): 241-251.

Smithey Fulmer, I. and R. E. Ployhart (2014). "'Our Most Important Asset": A Multidisciplinary/Multilevel Review of Human Capital Valuation for Research and Practice." Journal of Management 40(1): 161-192.

Spitz-Oener, A. (2006). "Technical Change, Job Tasks, and Rising Educational Demands: Looking outside the Wage Structure." Journal of Labor Economics 24(2): 235-270.

Steinmann, D. O. (1976). "The effects of cognitive feedback and task complexity in multiple-cue probability learning." Organizational Behavior and Human Performance 15(2): 168-179.

Sterling, A. and P. Boxall (2013). "Lean production, employee learning and workplace outcomes: a case analysis through the ability-motivation-opportunity framework." Human Resource Management Journal 23(3): 227-240.

Sung, J. and D. N. Ashton (2015). Skills in business. The role of business strategy, sectoral skills development and skills policy. Thousand Oakes, Sage.

Sweller, J. (1988). "Cognitive load during problem solving: Effects on learning." Cognitive Science 12(2): 257-285.

ter Doest, L. and J. De Jonge (2006). "Testing causal models of job characteristics and employee wellbeing: A replication study using cross-lagged structural equation modelling." Journal of Occupational and Organizational Psychology 79(3): 499-507.

Tims, M. and A. B. Bakker (2010). Job crafting: Towards a new model of individual job redesign.

Tims, M., A. B. Bakker, et al. (2012). "Development and validation of the job crafting scale." Journal of Vocational Behavior 80(1): 173-186.

Tsai, P. C.-F., Y.-F. Yen, et al. (2007). "A study on motivating employees' learning commitment in the post-downsizing era: Job satisfaction perspective." Journal of World Business 42(2): 157-169.

van der Velden, R. and D. Verhaest (forthcoming). "Are skill deficits always bad? Towards a learning perspective on skill mismatches. ." Research in Labor Economics.

Van Dyne, L., L. L. Cummings, et al. (1995). Extra role behaviors: in pursuit of construct and definition clarity. Research in Organizational Behavior. L. L. Cummings and B. M. Staw. Greenwich, CT, JAI Press. 17: 215-285.

van Merriënboer, J. G. and J. Sweller (2005). "Cognitive Load Theory and Complex Learning: Recent Developments and Future Directions." Educational Psychology Review 17(2): 147-177.

Watkins, K. E. and V. J. Marsick (2003). "Summing Up: Demonstrating the Value of an Organization's Learning Culture." Advances in Developing Human Resources 5(2): 129-131.

Wielenga-Meijer, E. G. A., T. W. Taris, et al. (2010). "From task characteristics to learning: A systematic review." Scandinavian Journal of Psychology 51(5): 363-375.

Wood, R. E. (1986). "Task complexity: Definition of the construct." Organizational Behavior and Human Decision Processes 37(1): 60-82.

Wowak, K. D., C. W. Craighead, et al. (2013). "Supply Chain Knowledge and Performance: A MetaAnalysis." Decision Sciences 44(5): 843-875. 
Yang, B., K. E. Watkins, et al. (2004). "The construct of the learning organization: Dimensions, measurement, and validation." Human Resource Development Quarterly 15(1): 31-55.

Youndt, M. A., S. A. Snell, et al. (1996). "Human Resource Management, Manufacturing Strategy, and Firm Performance." The Academy of Management Journal 39(4): 836-866. 


\section{Data Appendix: Scales}

The attitude to learning scale used in the survey consisted of 5 items - items 1,2,3,9, and 10 - of the scale measuring the disposition towards lifelong learning (Kirby, Knapper et al. 2010). All 5 items were administered to the survey participants that took the internet version, while participants taking the telephone interview were asked only one item (item 1). Higher scores on the scale and on each item corresponded to more favourable attitudes towards learning.

The scale used to measure workplace dynamism or workplace change was based on the following four items: "In the last five years have changes to the technologies you use (e.g. machinery, ICT systems)/ to your working methods and practices (e.g. how you are managed or how you work)/ to the products/services you help to produce/ to the amount of contact you have with clients or customers (e.g. dealing with customer/client queries or complaints) taken place in your workplace?" The answers were "Yes" or "No". High values on the scale meant a high degree of workplace dynamism.

The three items used to derive the change-in-complexity measure were: "Have the variety of tasks/ the difficulty of the tasks/ the need to learn new things increased, decreased or remained the same since you started your job with your current employer?" The answers were based on a 1 to 10 Likert scale, where 0 meant that the item had decreased greatly, 5 meant that it had stayed the same, and 10 meant that it had increased greatly. High values on the scale meant increased job complexity (Cronbach alpha $=0.84)$.

The scales for workplace dynamism and workplace were also derived by factor analysis. The stability of the scales thus obtained across countries was checked by Confirmatory Factor Analysis (Brown 2006). Note that the scale on changes in workplace complexity based on factor analysis and the one derived in the text (taking the average of the measures on the three items) have a correlation coefficient of 0.992 . 
Figure 1: The strength of the relationship between increases in job complexity and skills development in the pooled sample and across individual countries: coefficients and confidence interval bounds.

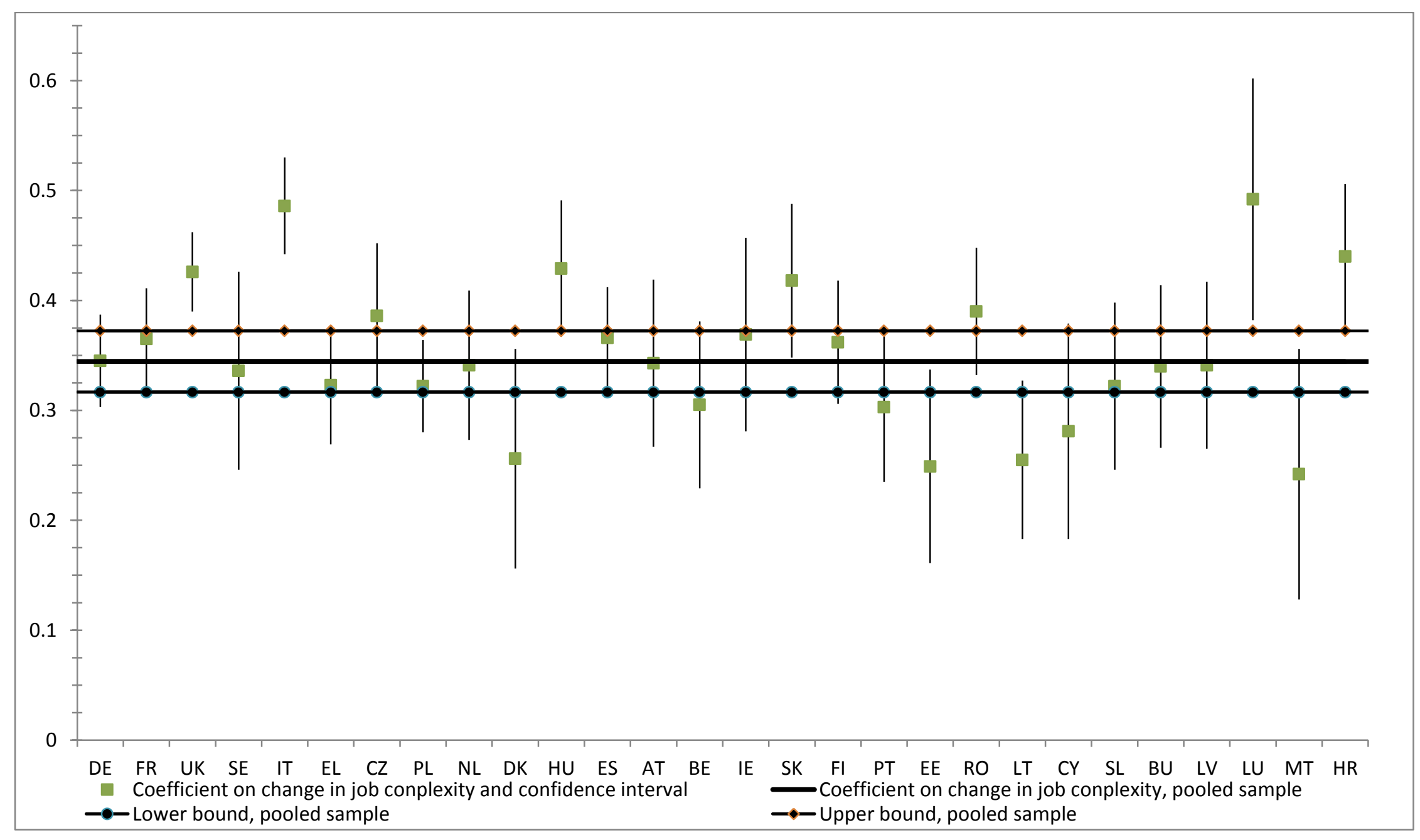


Figure 2: The strength of the relationship between increases in job complexity and skills development in the pooled sample and across occupations (1 digit ISCO codes: coefficients and confidence interval bounds.

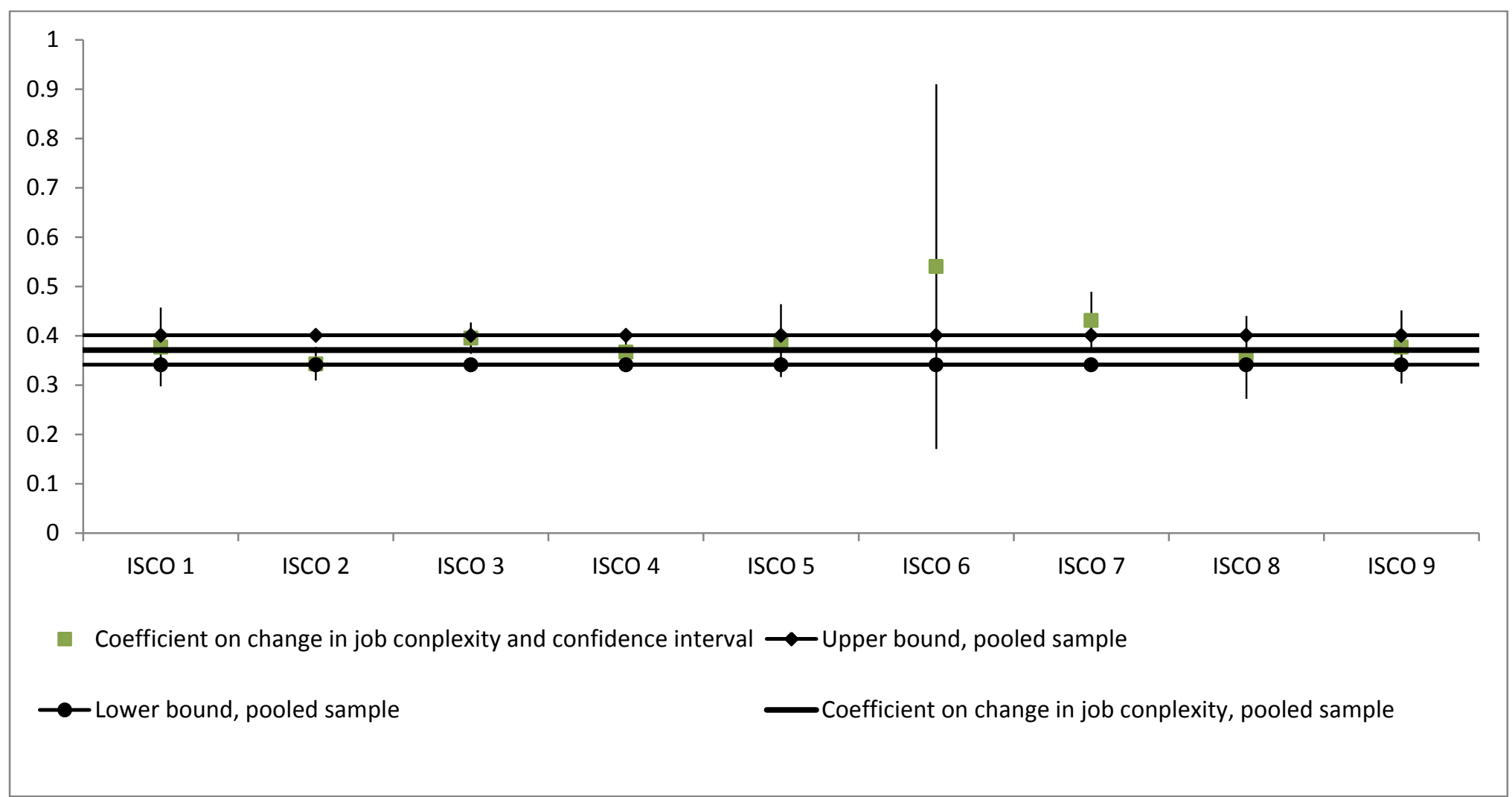

